\title{
A 3-Stage Treatment System For Domestic Wastewater: Part II. Performance Evaluation
}

\author{
Oon, Y. W. ${ }^{1}$, Law, P. L. ${ }^{2}$, Ting, S. N. ${ }^{3}$, Tang, F. E ${ }^{4}$
}

\begin{abstract}
A 3-stage micro-scale wastewater treatment system that consisted of 1) a spiral-framed human hair-based filter, 2) a plastic medium mixed flow biotower, and 3) a free surface water wetland system filled with Pistia Stratiotes (water lettuce) operating in series was recently developed and performance tests were conducted. Performance tests were carried out to determine the efficiencies of the system for removal of physically emulsified and free oils, organic matters such as biochemical oxygen demand, ammoniacal-nitrogen, suspended solids, and nutrients such as nitrogen, phosphorous, and potassium from semisynthetic wastewaters. From this study, it was found that the human hair-based filter could retain approximately $73.5 \%$ of physically emulsified oils, while the mixed flow biotower was capable of reducing approximately $35.0 \%$ biochemical oxygen demand, $57.4 \%$ ammoniacal-nitrogen, $51.8 \%$ nitrogen, $13.4 \%$ phosphorus, $21.8 \%$ potassium, and $21.9 \%$ reduction in turbidity. The Pistia Stratiotes-based free surface water wetland was found to remove approximately $24.1 \%$ biochemical oxygen demand, $30.6 \%$ ammoniacal-nitrogen, $38.0 \%$ nitrogen, $41.5 \%$ phosphorus, $46.7 \%$ potassium and $31.7 \%$ reduction in turbidity. When the mixed flow biotower and free surface water wetland system were to operate in series, the combined removal efficiencies were approximately $59.2 \%$ for biochemical oxygen demand, $\mathbf{8 7 . 9 \%}$ for ammoniacal-nitrogen, $90.6 \%$ for nitrogen, $54.9 \%$ for phosphorus, $\mathbf{6 8 . 5 \%}$ for potassium, and $59.0 \%$ reduction in turbidity. Experimental data also showed that daily uptake rates (mg/kg-day) of organics and nutrients by per kilogram of Pistia Stratiotes were approximately 1,731 mg for biochemical oxygen demand, 1,015 mg for ammoniacal-nitrogen, 1,206 mg for nitrogen, 1,468 mg for phosphorus, and 5,431 mg for potassium.
\end{abstract}

Keywords: Performance tests, human hair, spiral framed, biotower, free surface water wetland, Pistia Stratiotes

\section{INTRODUCTION}

$\mathrm{T}$

HE main operating processes of the recently developed 3-stage wastewater treatment system include; 1) spiral-framed human hair-based filter (HBF) (figure 1) with liquid flowing in a spiral plane [1], [3], [4], [7], [9], [10], [12], [17], [20], [24], [25], [26], [29], [30], [32]; 2) mixed flow biotower (MFB) (figure 2), which is an aerobic attached-growth biological treatment method by nitrification [2], [6], [11], [13], [15], [16], [21], [23], [28], [31], [33], [34]; and 3) Pistia Stratiotesbased free surface water (FSW) wetland (figure 3) process that applies the principles of biodegradation of organic matters by bacteria and water lettuce uptake of nutrients [6], [18], [19], [22], [26], [27]. This research focused on the performance evaluation of the recently developed 3-stage micro-scale domestic wastewater treatment system with HBF, MFB and FSW wetland connected in series. Experimental details and sampling locations were presented in figure 4, figure 5 and figure 6. Field tests were carried out to determine the removal efficiencies of; 1) physically emulsified and free oils by HBF; 2) biochemical oxygen demand (BOD), ammoniacal-nitrogen $\left(\mathrm{NH}_{3}-\mathrm{N}\right)$, and suspended solids (SS) by $\left.\mathrm{MFB} ; 3\right) \mathrm{BOD}, \mathrm{NH}{ }_{3}-\mathrm{N}$, SS, nitrogen (N), phosphorus (P), and potassium (K) by FSW wetland system; and 4) combined removal efficiencies of those parameters when the HBF, MFB and FSW wetland components were to operate in series.

The experimental work was conducted for a period of 30 days at the Environmental Engineering Laboratory of the Department of Civil Engineering, University of Malaysia Sarawak (UNIMAS). The trial runs period extended from $2^{\text {nd }}$ to $10^{\text {th }}$ of February 2006 to make sure that stabilized conditions were attained. Actual sampling and analysis began from $11^{\text {th }}$ February 2006 to $2^{\text {nd }}$ March 2006 for HBF; from $10^{\text {th }}$ July 2006 to $22^{\text {nd }}$ July 2006 for MFB and FSW wetland. A total of 6 batches (for HBF) and 9 batches (for MFB and FSW wetland) of data were collected at the individual points of the system and analyzed.

\section{MATERIALS AND METHODS}

Influent Wastewater Source

In this research, wastewater samples were prepared using raw water collected from one of the facultative ponds at the East Campus (Old Campus) of the UNIMAS. It was noted the that pond water composed of a mixture of septic tank effluents and wastewaters generated from food courts, pantries, laboratories, and storm waters, which also contained extremely low amount of emulsified oils, BOD, $\mathrm{NH}_{3}-\mathrm{N}, \mathrm{SS}, \mathrm{N}, \mathrm{P}$, and $\mathrm{K}$.

\footnotetext{
${ }^{1}$ Oon, Y. W., Student of Civil Engineering Department, Universiti Malaysia Sarawak (e-mail: oonyinwee@gmail.com)

${ }^{2}$ Law, P. L., Professor of Civil Engineering Department, Universiti Malaysia Sarawak (e-mail: puonglaw@ feng.unimas.my)

${ }^{3}$ Ting, S. N., Senior Lecturer of Civil Engineering Department, Universiti Malaysia Sarawak (e-mail: snting@ feng.unimas.my

${ }^{4}$ Tang, F. E., Senior Lecturer of Civil \& Construction Engineering Department, Curtin University of Technology (Sarawak Campus)(email: tang.fu.ee@curtin.edu.my)
} 
UNIMAS E-Journal of Civil Engineering, Vol. 4: Issue 1/April 2013

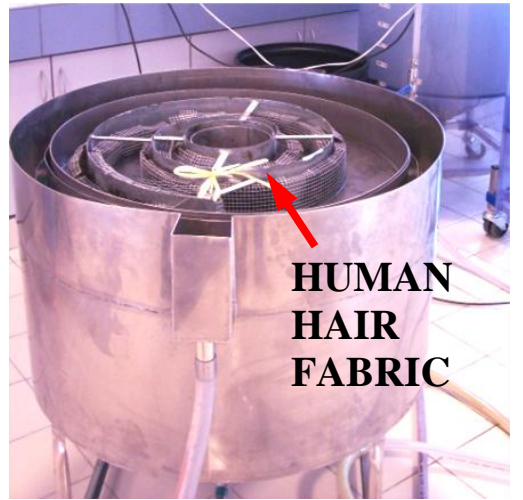

(a)

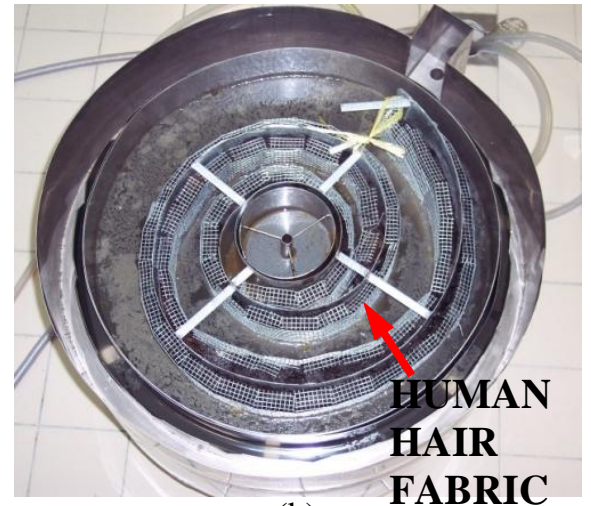

(b)

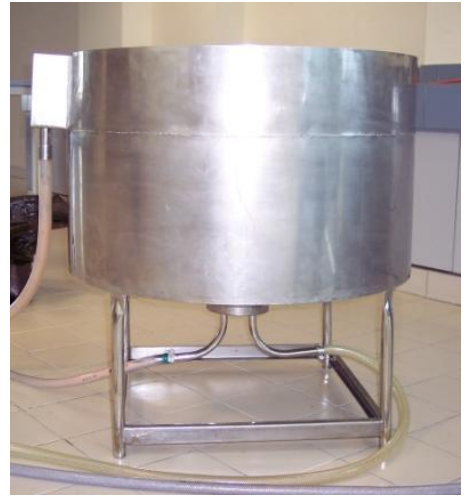

(c)

Figure 1. a) Perspective view; b) Top view ; c) Side view of HBF

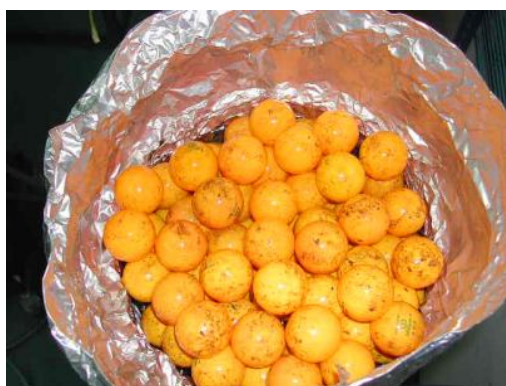

(a)

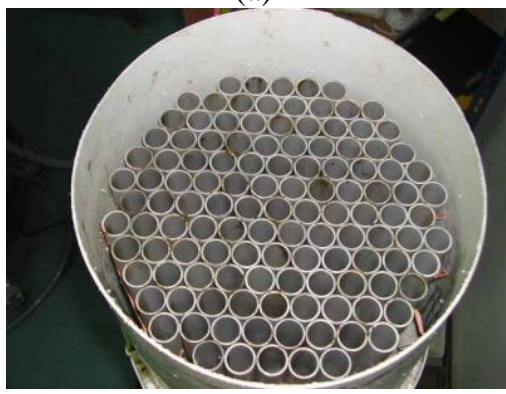

(b)

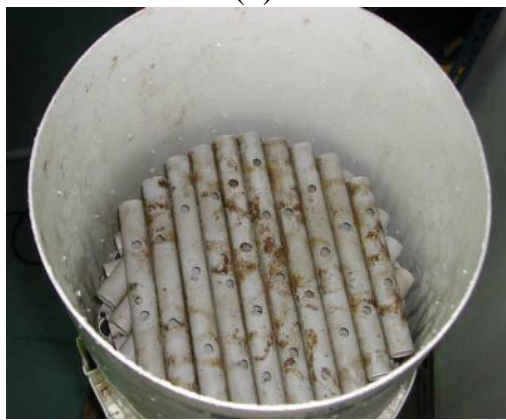

(c)

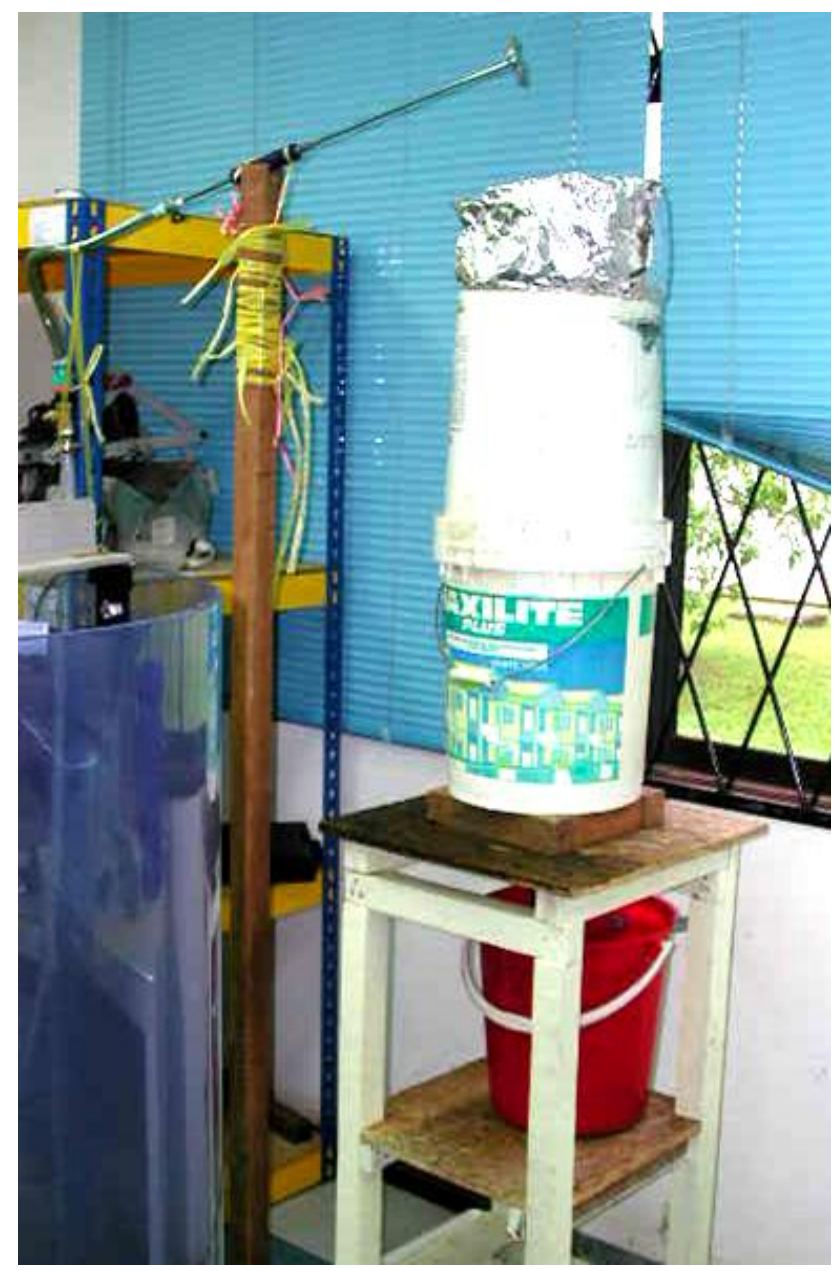

(d)

Figure 2. a) Top Spherical Layer; b) Vertical Flow Medium; c) Cross Flow Medium and d) Overall Setup Of MFB System 
UNIMAS E-Journal of Civil Engineering, Vol. 4: Issue 1/April 2013

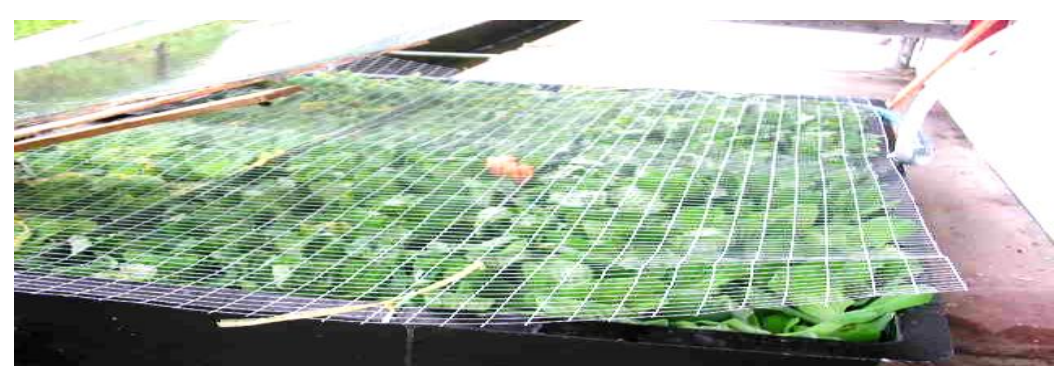

Figure 3. Pistia Stratiotes-Based FSW Wetland 


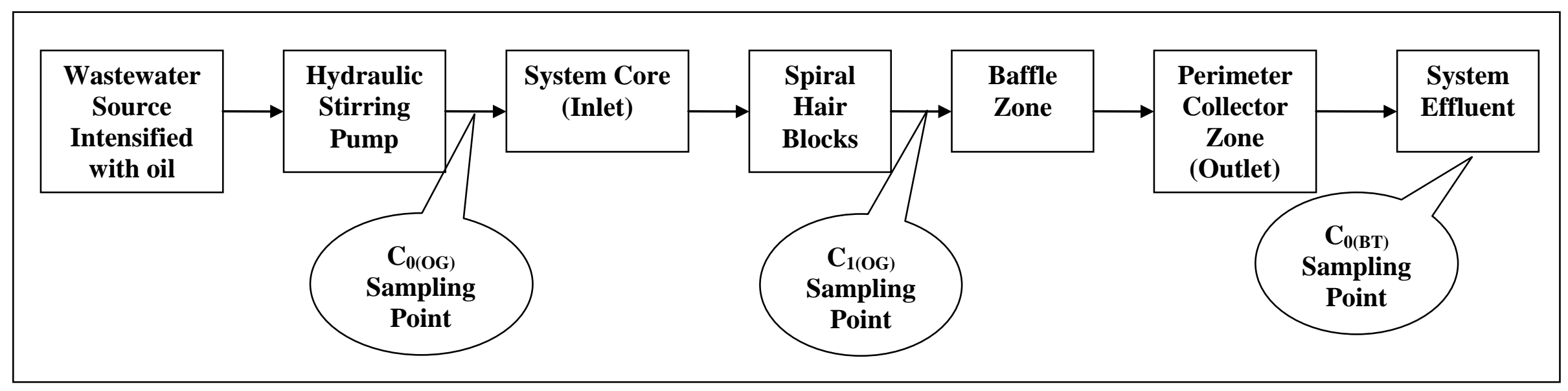

Figure 4. Process Flow and Sampling Points for "Center-Feed Upflow (CFU)" Arrangement

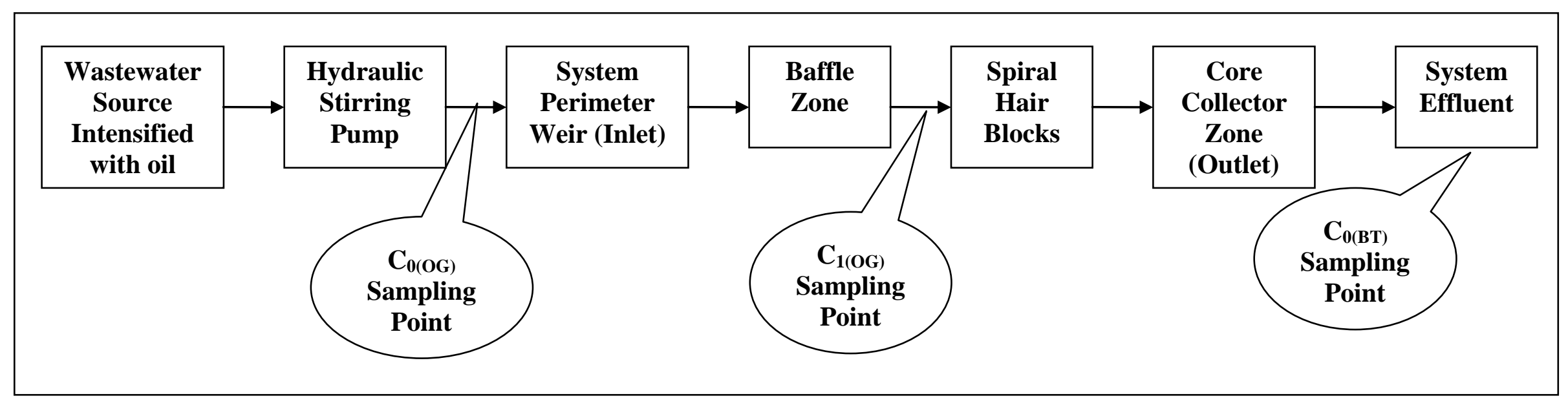

Figure 5. Process Flow and Sampling Points for "Peripheral-Feed Center Downflow (PFD)" Arrangement. 


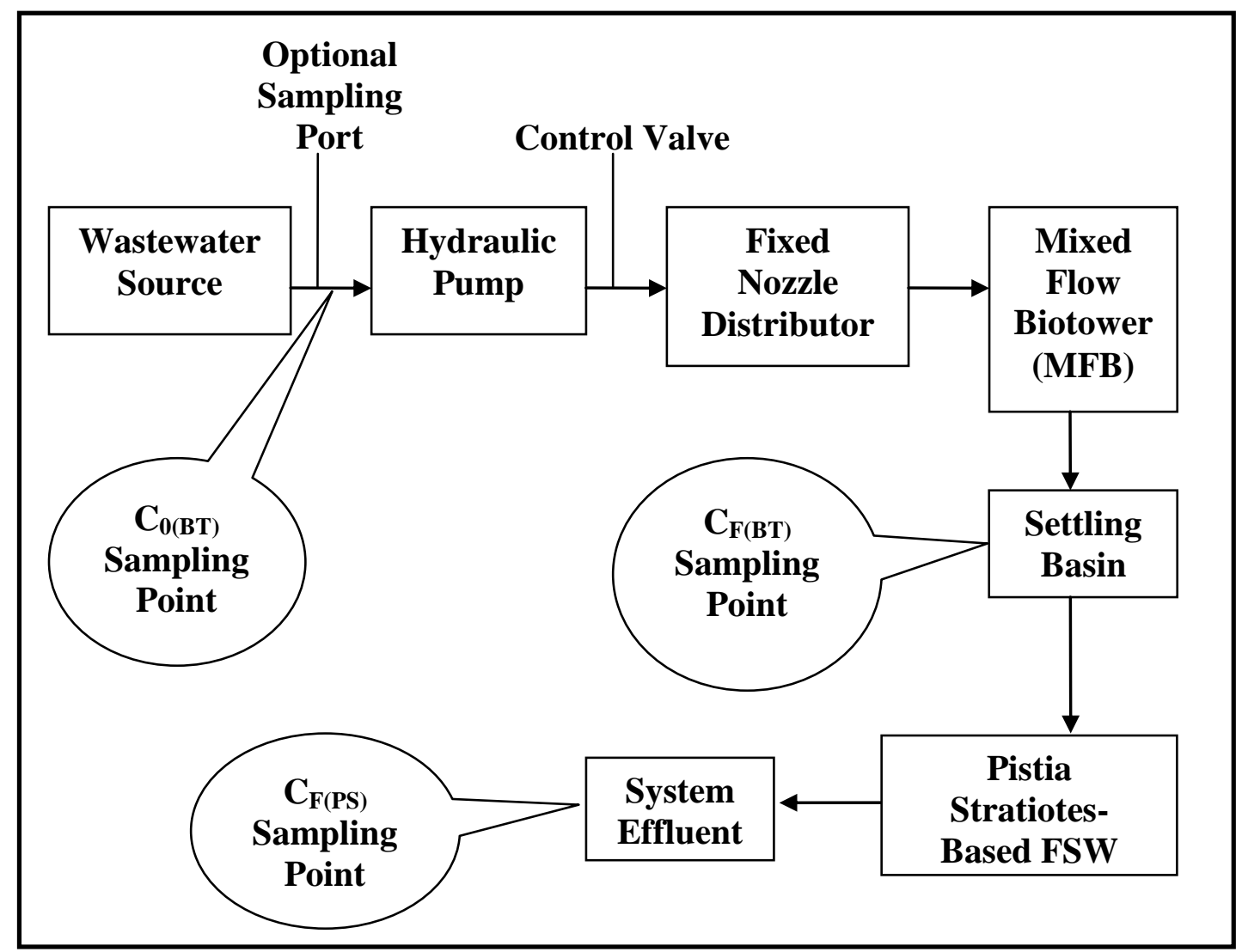

Figure 6. Process Flow and Sampling Points at MFB \& FSW Wetland

Wastewaters were intensified with edible oil (cooking oil) before being pumped into the HBF by a hydraulic stirring pump. Two patterns of flow were tested; 1) Core-Baffle-Perimeter as shown in figure 4; and 2) Perimeter-Baffle-Core as shown in figure 5 to determine the efficiencies of the filter system. Control valves were used to stabilize the system by regulating the system's flow rate during the experimental work. The effluent from HBF was then transported by a hydraulic pump to the biotower (MFB) and applied onto the top layer of MFB using a fixed nozzle distributor. The overall experimental setup details, process flow and wastewater sampling points were shown in figure 4, figure 5 and figure 6 . Because of the hydraulic gradient factor, a 6-metre pressure head submersible hydraulic pump was chosen for this experiment.

The flowrate through the fixed nozzle distributor was controlled by a valve to permit a desired flow at approximately 185 liters/day (L/day) to minimize the impact of shear velocity on the attached growth. This system has an under drain that collects the filtrate and solids, which also served as a source of air for the microorganisms to maintain aerobic conditions in the MFB. Sufficient air supply would be provided by natural draft and wind forces through ventilation ports at the bottom of the MFB. The MFB effluents were gravitated to the settling basin.

The Pistia Stratiotes-based FSW wetland system was designed to provide a surface overflow rate of approximately 167.70 liters/day. $\mathrm{m}^{2}$, detention time of 24 hours (1.0 day), and horizontal velocity of $5.15\left(10^{-3}\right) \mathrm{m} / \mathrm{hr}(0.17 \mathrm{ft} / \mathrm{hr})$. In this study, a total of 47 units of approximately equally sized Pistia Stratiotes were used with the total plant mass of approximately 1.69 $\mathrm{kg}$. This FSW wetland system was placed outdoor sheltered by a transparent plastic sheet to avoid external disturbances such as rain waters. Pistia Stratiotes was characterized by having high number of suspended roots of over one foot long and longer roots are believed to have higher uptake capacity [5], [6], [21].

\section{Sampling and Analysis}

In this study, the intensified raw wastewater samples abbreviated as $\mathrm{C}_{\mathrm{o}(\mathrm{OG})}$ (HBF influent) were collected at locations prior to influent to the hair-based spiral filter. A valve was located between the hydraulic stirring pump and filter to regulate flow rate .The influents were either discharged into the system through the system core or the peripheral weir as the inlet. Then the wastewater flowed into a spiral plane filled with hair blocks and intermediated with a baffle zone before reaching the outlet (perimeter or core, and vice-versa) (figure 4 and figure 5). The effluent of the hair-based spiral tank was taken as $\mathrm{C}_{0(\mathrm{BT})}$. It acted as the influent to the next stage of the filtration process. Before discharging directly into the mixed flow MFB, the influent $\mathrm{C}_{0(\mathrm{BT})}$ flow was controlled by a valve at a flowing rate of $185 \mathrm{~L} /$ day and a spraying nozzle was used to provide uniform droplets distribution onto the top layer of the filter. The wastewater then trickled down from the top layer to the bottom by gravity and was collected in the settling basin. Samples were collected from the settling tank and abbreviated as $\mathrm{C}_{\mathrm{F}(\mathrm{BT})}$ (MFB effluent). MFB effluents $\left(\mathrm{C}_{\mathrm{F}(\mathrm{BT}}\right)$ were then channelled to the hyacinth-based FSW wetland system as influent. Samples were then collected from the effluent of the hyacinth-based FSW wetland system abbreviated as $\mathrm{C}_{\mathrm{F}(\mathrm{PS})}$. Temperature, $\mathrm{pH}$, and turbidity at the sampling points were also monitored regularly and recorded throughout this experimental period. 
Samples drawn at individual points as $\mathrm{C}_{\mathrm{o}(\mathrm{OG})}$ and $\mathrm{C}_{1(\mathrm{OG})}$ were analyzed at Environmental Engineering Laboratory,

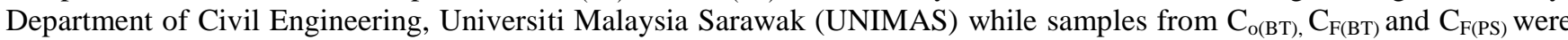
analyzed at "Nabbir Laboratory (Sarawak) Sdn Bhd" (accredited by Natural Resources and Environmental Board and Department of Environmental, Malaysia) located at Lot 2406, Batu Kitang Light Industrial Park, $7^{1 / 2}$ Mile, Jalan Batu Kitang, 93250 Kuching, Sarawak. Some of the major analysis equipments and methods used in this study included Spectrophotometer (8038, 8075, 8048 and 8237; 2), Dissolved Oxygen (DO) meter (APHA 5210B), Atomic Absorption (AA) Spectrophotometer (APHA $3500 \mathrm{~KB}$ ), and Oil in Water Analyzer [8], [14].

\section{RESULTS AND DISCUSSION}

$\mathrm{F}_{1}$ IGURE 7(a) and figure 8(a) show a comparison of removal efficiencies of O\&G by the spiral-framed hair-based filter (HBF) with CFU pattern. The HBF achieved an average reduction of $52.9 \mathrm{mg} / \mathrm{L}$ (equivalent to $36.5 \%$ reduction) at the CoreBaffle Zone and $22.8 \mathrm{mg} / \mathrm{L}$ reduction (15.8\% in reduction) at Baffle-Periphery Zone. The overall removal efficiency for the CFU pattern was approximately $53 \%$ (i.e. $36.5 \%$ at Core-Baffle Zone and $15.8 \%$ at Baffle-Periphery Zone). It was shown that the efficiency of Baffle-Periphery Zone marginally exceeded $50 \%$ of the system's overall efficiency. From the test data, the system had demonstrated its potential for removal of $O \& G$ although the efficiency was not remarkable.

Figure 7(b) shows the amount of reduction in oil droplet levels for PFD pattern, while figure 8(b) shows the system's removal efficiencies of O\&G. Average reductions were $24.4 \mathrm{mg} / \mathrm{L}$ (26.2\% reduction) at Periphery-Baffle Zone, and 44.2 $\mathrm{mg} / \mathrm{L}(47.3 \%$ reduction) at Baffle-Core Zone. It was demonstrated that the overall removal efficiency was approximately $73.5 \%$ (i.e. approximately $26.2 \%$ at Periphery-Baffle Zone and $47.3 \%$ at Baffle-Core Zone). From the data collected, it was observed that this pattern resulted in higher oil droplet reduction at Periphery-Baffle Zone as compared to Baffle-Core Zone. It was also demonstrated that PFD pattern achieved higher overall O\&G removal efficiency as compared to CFU pattern. The levels of reduction observed at Baffle-Core Zone for CFU and PFD were approximately 36.5\% and 47.3\%, respectively. These data proved the workability of the spiral frustum design of HBF.

Figure 9 and figure 15 illustrate the BOD removal efficiencies of MFB and FSW wetland with respect to the amount of BOD reductions during the experimental period. The biotower demonstrated a consistent removal rate regardless of influent concentrations, with an average removal efficiency of approximately 35.0\%. Similarly, the Pistia Stratiotes-based FSW wetland recorded an average removal rate of approximately $24.1 \%$. The combined BOD removal rate of the two components, i.e., MFB and FSW wetland operating in series was approximately $59.2 \%$. It can be concluded that the combined MFB and FSW wetland operating in series can achieve more than $50 \%$ removal rate of BOD.

Figure 10 and figure 15 show the observed removal efficiencies of $\mathrm{NH}_{3}-\mathrm{N}$ by MFB and FSW wetland from wastewaters. The average $\mathrm{NH}_{3}-\mathrm{N}$ removal efficiency achieved by the biotower recorded $57.4 \%$ and the reduction rate (mg/L) was rather consistent throughout the experimental period regardless of influent $\mathrm{NH}_{3}-\mathrm{N}$ levels. As shown in figure 10 and figure 15 , the FSW wetland demonstrated a similar consistent achievable effluent level to less than $2 \mathrm{mg} / \mathrm{L}$, regardless of the influent $\mathrm{NH}_{3-}$ $\mathrm{N}$ levels. This indicates that Pistia Stratiotes has an extremely high uptake capacity of $\mathrm{NH}_{3}-\mathrm{N}$. As observed, it was demonstrated that $\mathrm{NH}_{3}-\mathrm{N}$ levels would substantially be reduced by both the MFB and FSW wetland. When the MFB and FSW wetland were to operate in series, the overall achievable removal efficiency of $\mathrm{NH}_{3}-\mathrm{N}$ could be as high as $87.9 \%$.

Plots of total nitrogen $(\mathrm{N})$ measured at the influents and effluents of MFB and FSW wetland with respect to time are illustrated in figure 11 and figure 15. The average amount of reduction in total nitrogen recorded between $\mathrm{C}_{0(\mathrm{BT})}$ and $\mathrm{C}_{\mathrm{F}(\mathrm{BT})}$ was approximately $51.8 \%$ by $\mathrm{MFB}$, and between $\mathrm{C}_{\mathrm{F}(\mathrm{BT})}$ and $\mathrm{C}_{\mathrm{F}(\mathrm{PS})}$ indicated a $38.8 \%$ reduction by FSW wetland. When the MFB and FSW wetland operated in series, the overall average total nitrogen removal efficiency could be as high as $90.6 \%$. When the performance of the system is expressed in $\mathrm{N}$ removed from per liter $(\mathrm{mg} / \mathrm{L})$ of wastewater, the MFB attained an average of $0.99 \mathrm{mg} / \mathrm{L}$, whilst the FSW wetland achieved approximately $1.01 \mathrm{mg} / \mathrm{L}$. The plots in figure 10 and figure 11 show that the patterns of total nitrogen reduction in the wastewater samples observed were similar to $\mathrm{NH}_{3}-\mathrm{N}$. This could be due to the direct relationship between $\mathrm{NH}_{3}-\mathrm{N}$ and total nitrogen because $\mathrm{NH}_{3}-\mathrm{N}$ molecules are generally formed by the nitrogen atoms after combining with hydrogen atoms to achieve stabilization. In the nitrogen cycle, the $\mathrm{NH}_{3}-\mathrm{N}$ would be transformed to nitrite and nitrate or backward through nitrification or denitrification processes. Thus, a reduction in $\mathrm{NH}_{3}-\mathrm{N}$ would give a lower total nitrogen level.

Figure 12 and figure 15 illustrate the differences in phosphorous $(\mathrm{P})$ levels between $\mathrm{C}_{0(\mathrm{BT})}$ and $\mathrm{C}_{\mathrm{F}(\mathrm{BT})}$, and between $\mathrm{C}_{\mathrm{F}(\mathrm{BT})}$ and $\mathrm{C}_{\mathrm{F}(\mathrm{PS})}$ respectively. The amount of P reduced by MFB was approximately $13.4 \%$, while the Pistia Stratiotes-based FSW wetland achieved approximately $41.5 \%$. This indicates that the removal of P by FSW wetland was $28.1 \%$ higher than MFB. When the performances are expressed in $\mathrm{mg} / \mathrm{L}$ of $\mathrm{P}$ reduced in the wastewaters, the observed data collected during experimental period demonstrated that MFB achieved an average of $0.57 \mathrm{mg} / \mathrm{L}$ reduction in $\mathrm{P}$, while the FSW wetland achieved an average of $1.25 \mathrm{mg} / \mathrm{L}$. When the MFB and FSW wetland were to operate in series, the combined overall removal efficiency of the system was approximately $54.9 \%$.

In this research, the potassium $(\mathrm{K})$ levels in the raw wastewater influents of the MFB were recorded in the range of 3.14 and $18.86 \mathrm{mg} / \mathrm{L}$. As illustrated in figure 13 and figure 15, the MFB had shown to be capable of removing an average of approximately $21.8 \%$ and FSW wetland attained an average of $46.7 \%$ reduction in $\mathrm{K}$ from wastewaters. This indicates that the K uptake rate of Prista Stratiotes was approximately $24.9 \%$ higher than the MFB. It was also demonstrated that when the MFB and FSW wetland were to operate in series, the combined overall removal efficiency for K could be as high as $68.5 \%$. 
In this study, effluent turbidity levels were measured in Nephelometry Turbidity Unit (NTU) for all collected wastewater samples [15]. The turbidity readings showed a decreasing trend as the wastewater moved through the treatment system. In figure 14 and figure 15, it is shown that FSW wetland system was capable of bringing down the average turbidity level to about 4 NTU, while the MFB was capable of reducing average turbidity level to approximately 8 NTU. The average reduction in turbidity levels were approximately $21.9 \%$ as achieved by the mixed flow biotower, $37.1 \%$ by FSW wetland system, and 59.0\% when the MFB and FSW wetland operated in series.

In table 1, it was shown that a value of $73.5 \%$ removal efficiencies for O\&G by HBF was recorded as the average value of the 2 flow patterns that were conducted in this experiment. The "Center-Feed Upflow (CFU)" and "Peripheral-Feed Center Downflow (PFD)" patterns recorded 53\% and 73.5\%, respectively. These data strongly indicated the workability of the spiral frustum design of $\mathrm{HBF}$.

As shown in table 1, the observed average removal efficiencies attained by MFB were 35.0\% BOD, 57.4\% ammoniacal nitrogen, $51.8 \%$ total nitrogen, $13.4 \%$ phosphorus, $21.8 \%$ potassium, and $21.9 \%$ reduction in turbidity. The FSW wetland had demonstrated its capability by removing an average of $24.1 \%$ BOD, 30.6\% ammoniacal-nitrogen, $38.8 \%$ nitrogen, $41.5 \%$ phosphorus, $46.7 \%$ potassium, and $37.1 \%$ reduction in turbidity. It was found that FSW wetland was relatively more efficient than MFB with respect to the removal of phosphorus and potassium. Also, it was demonstrated that the MFB was relatively more efficient for removal of BOD and total nitrogen than phosphorus and potassium. When the MFB and FSW wetland operated in series, the removal efficiencies (see table 1) were $73.5 \%$ for physically emulsified oils, 59.2\% for BOD, $87.9 \%$ for ammoniacal-nitrogen, $90.6 \%$ for total nitrogen, $54.9 \%$ for phosphorous, $68.5 \%$ for potassium, and $59.0 \%$ reduction in turbidity levels.

Table 1. Overall Removal Efficiencies, \% (When all 3 Stages Operated in Series)

\begin{tabular}{|l|c|c|c|c|}
\hline \multirow{2}{*}{ Parameters } & \multicolumn{3}{|c|}{ HBF\& Biotower \& FSW System Operating in Series } \\
\cline { 2 - 5 } & \multicolumn{3}{|c|}{ Removal Efficiency (\%) } \\
\cline { 2 - 5 } & $\begin{array}{c}\text { HBF } \\
(\boldsymbol{\%})\end{array}$ & $\begin{array}{c}\text { Biotower } \\
(\boldsymbol{\%})\end{array}$ & $\begin{array}{c}\text { FSW System } \\
(\boldsymbol{\%})\end{array}$ & $\begin{array}{c}\text { Combined System } \\
(\boldsymbol{\%})\end{array}$ \\
\hline Free Oils & 73.5 & - & - & 73.5 \\
\hline Biochemical Oxygen Demand & - & 35.0 & 24.1 & 59.2 \\
\hline Ammoniacal-nitrogen & - & 57.4 & 30.6 & 87.9 \\
\hline Nitrogen & - & 51.8 & 38.8 & 90.6 \\
\hline Phosphorus & - & 13.4 & 41.5 & 54.9 \\
\hline Potassium & - & 21.8 & 46.7 & 68.5 \\
\hline Turbidity & - & 21.9 & 37.1 & 59.0 \\
\hline
\end{tabular}

In this research, the mass increment of Pistia Stratiotes with respect to nutrient uptake rates was also studied. Table 2 shows the mass increment of Pistia Stratiotes versus nutrients uptakes by the hyacinth and the average removal of pollutants (nutrients) from wastewater by Pistia Stratiotes over a period of 11 days. The correlation of pollutants removal and hyacinth plants mass increment shows that when the plants size and mass increased, the uptakes of nutrients also increased causing a decrease in the concentration of nutrients in wastewater. The total mass of the plants increased by approximately $1.705 \mathrm{~kg}$ (from 1.66 to $3.365 \mathrm{~kg}$ ), which was approximately 1.03 times of the initial mass in a period of 11 days. The incremental mass of the plant was directly proportional to the total concentration of pollutants (nutrients) with respect to time. Therefore, with a flow rate of $185 \mathrm{~L} /$ day, the observed experimental data indicated that the daily uptake rate of organics and nutrients expressed in $\mathrm{mg} / \mathrm{kg}$-day, i.e., $\mathrm{mg}$ of organics and nutrients removed by one $\mathrm{kg}$ of Pistia Stratiotes per day were approximately 1,731 mg for BOD, $1015 \mathrm{mg}$ for $\mathrm{NH}_{3}-\mathrm{N}, 1,206 \mathrm{mg}$ for $\mathrm{N}, 1,468 \mathrm{mg}$ for P, and 5,431 mg for K.

Table 2. Total Mass of Pistia Stratiotes versus Pollutant Removal Rates

\begin{tabular}{|c|c|c|c|c|c|c|c|}
\hline \multirow[t]{2}{*}{ Parameters } & \multicolumn{3}{|c|}{ Mass of Pistia Stratiotes, $\mathrm{Kg}$} & \multicolumn{4}{|c|}{ Pollutant Concentration Levels, mg/L } \\
\hline & $\begin{array}{c}\text { Beginning } \\
\text { of } \\
\text { Experiment } \\
\text { Period }\end{array}$ & $\begin{array}{c}\text { End of } \\
\text { Experiment } \\
\text { Period }\end{array}$ & $\begin{array}{c}\text { Increase } \\
\text { in Mass } \\
\text { of Pistia } \\
\text { Stratiotes }\end{array}$ & $\begin{array}{c}\text { Beginning } \\
\text { of } \\
\text { Experiment } \\
\text { Period }\end{array}$ & $\begin{array}{c}\text { End of } \\
\text { Experiment } \\
\text { Period }\end{array}$ & $\begin{array}{l}\text { Removal } \\
\text { Rate }\end{array}$ & $\begin{array}{c}\text { Average } \\
\text { Removal } \\
\text { Rate }\end{array}$ \\
\hline $\begin{array}{l}\text { Biochemical } \\
\text { Oxygen Demand }\end{array}$ & \multirow{5}{*}{1.66} & \multirow{5}{*}{3.365} & \multirow{5}{*}{1.705} & 42 & 26 & 16 & 1.45 \\
\hline $\begin{array}{l}\text { Ammonical- } \\
\text { Nitrogen }\end{array}$ & & & & 11.11 & 1.76 & 9.4 & 0.85 \\
\hline Nitrogen & & & & 12.85 & 1.74 & 11.1 & 1.01 \\
\hline Phosphorus & & & & 27.6 & 14.08 & 13.5 & 1.23 \\
\hline Potassium & & & & 91.06 & 41.01 & 50.1 & 4.55 \\
\hline
\end{tabular}




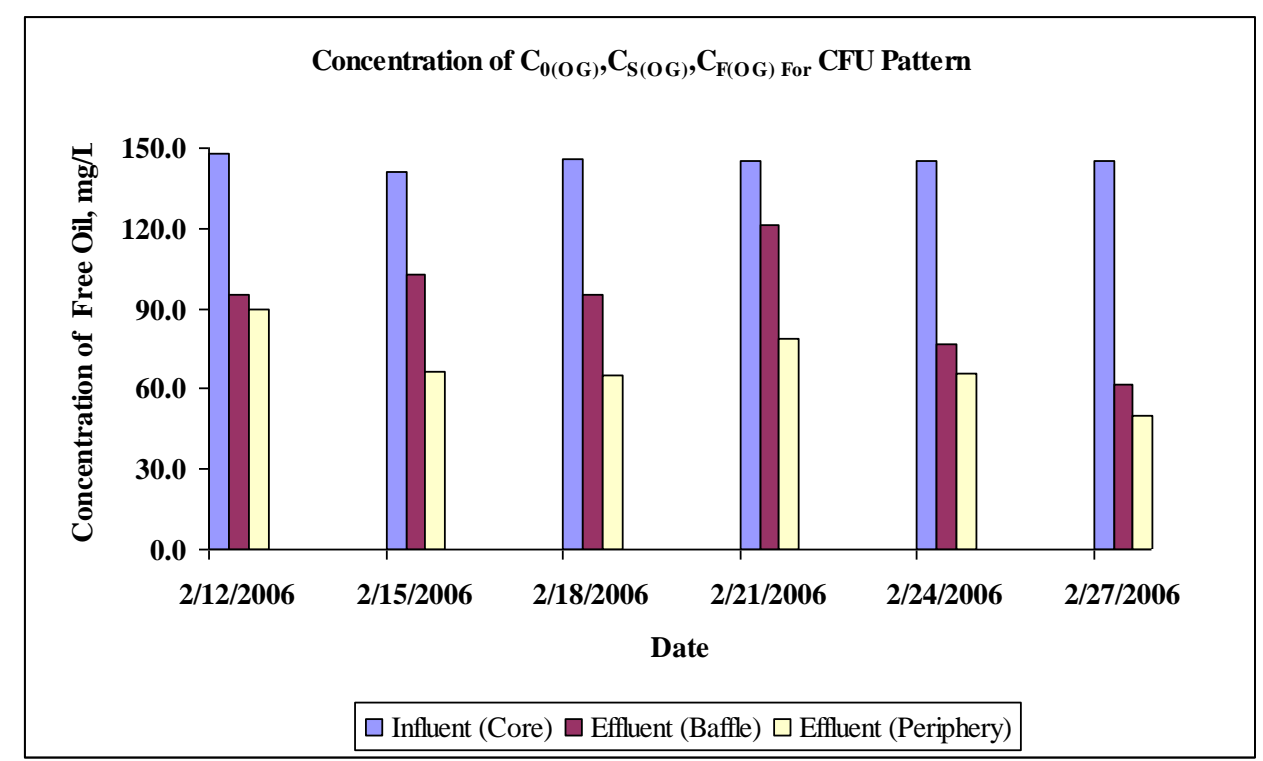

Figure 7(a). Influent Oil Concentration of Core Zone $\mathrm{C}_{0(\mathrm{OG})}$, Effluent of Baffle Zone $\mathrm{C}_{\mathrm{S}(\mathrm{OG})}$, Effluent of Periphery Weir Zone $\mathrm{C}_{\mathrm{F}(\mathrm{OG})}$ for CFU Flow Pattern

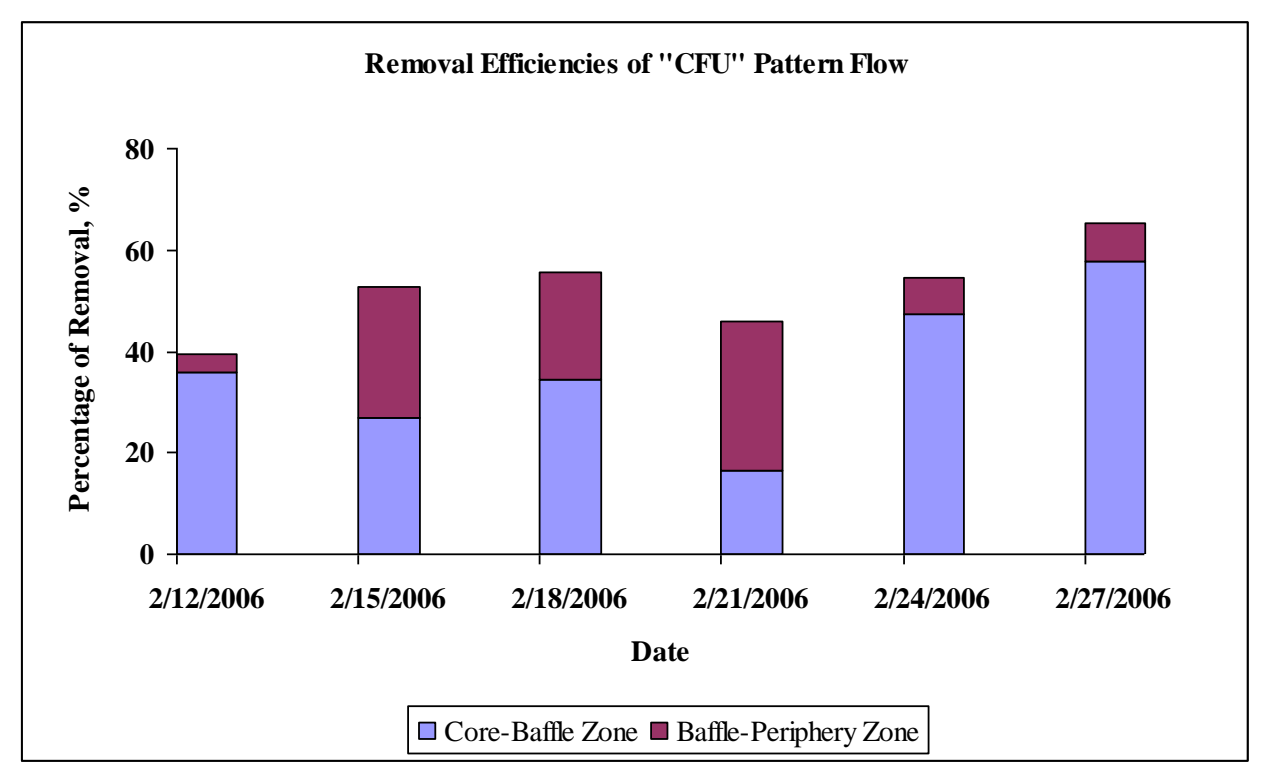

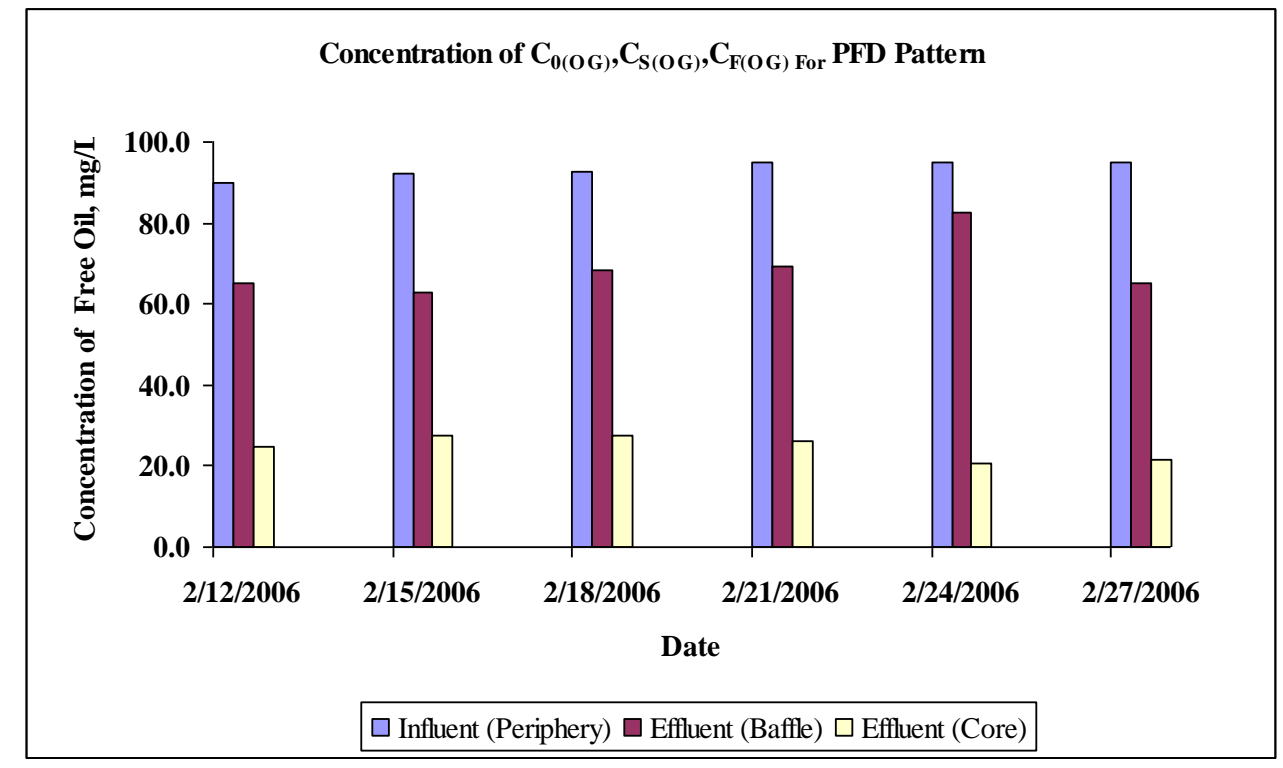

Figure 7(b). Influent Oil Concentration of Periphery Weir Zone $\mathrm{C}_{0(\mathrm{OG})}$, Effluent of Baffle Zone $\mathrm{C}_{\mathrm{S}(\mathrm{OG})}$, Effluent of Core Zone $\mathrm{C}_{\mathrm{F}(\mathrm{OG})}$ for PFD Flow Pattern

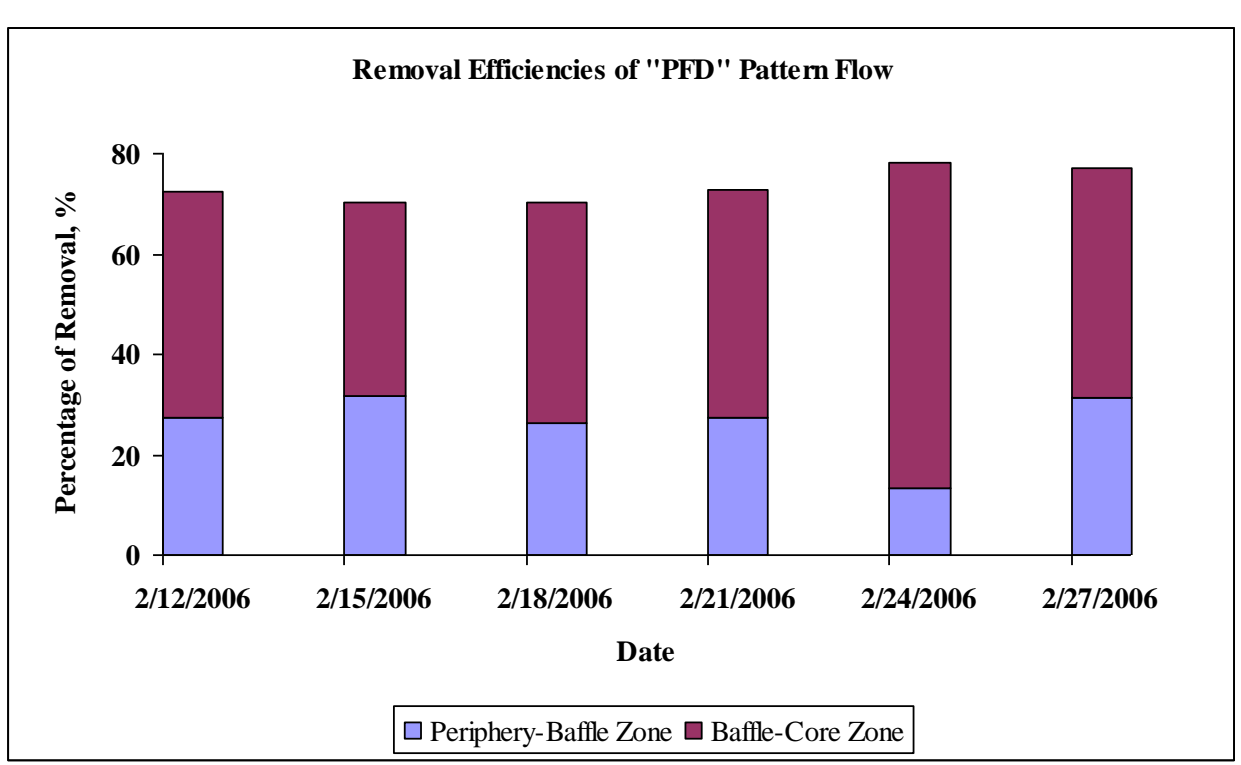


UNIMAS E-Journal of Civil Engineering, Vol. 4: Issue 1 /April 2013

Figure 8(a). Observed Overall Removal Efficiency of HBF for CFU Flow Pattern

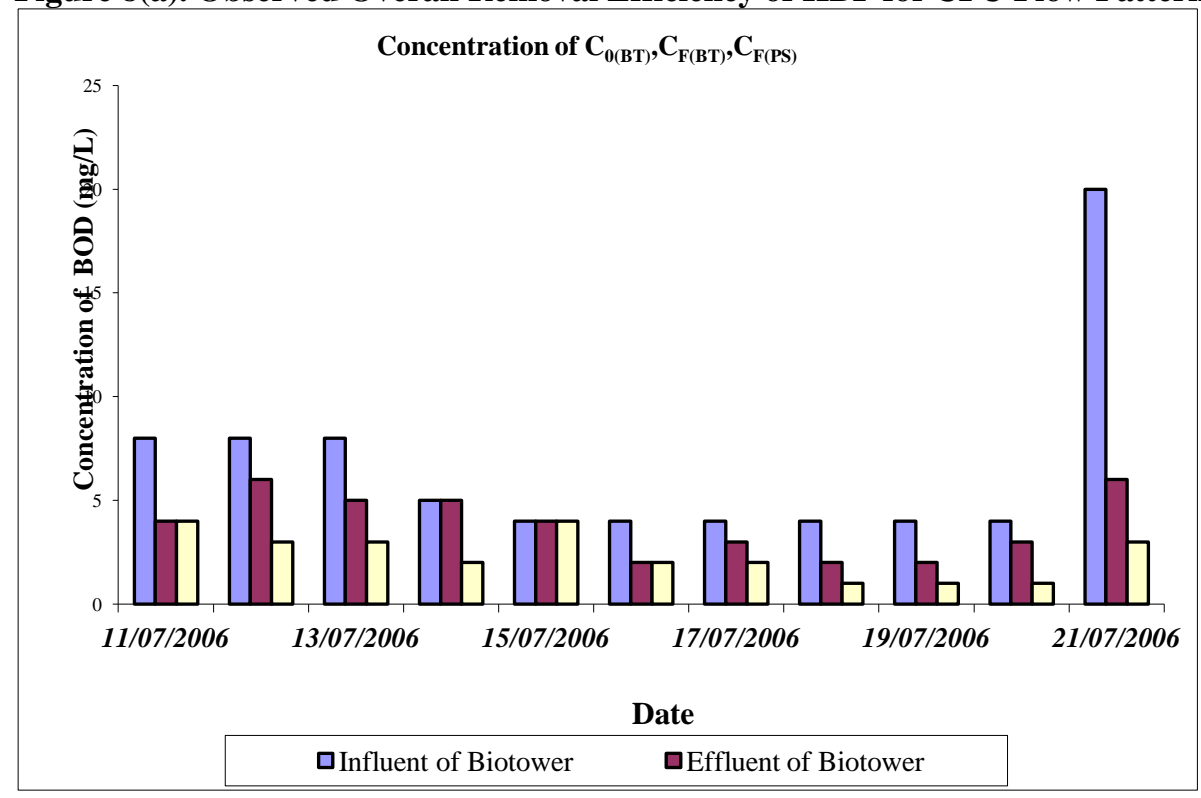

Figure 9. $\mathrm{BOD}_{5}$ Levels at $\mathrm{C}_{0(\mathrm{BT})}, \mathrm{C}_{\mathrm{F}(\mathrm{BT})}$ and $\mathrm{C}_{\mathrm{F}(\mathrm{PS})}$ versus Detention Time
Figure 8(b). Observed Overall Removal Efficiency of HBF for PFD Flow Pattern

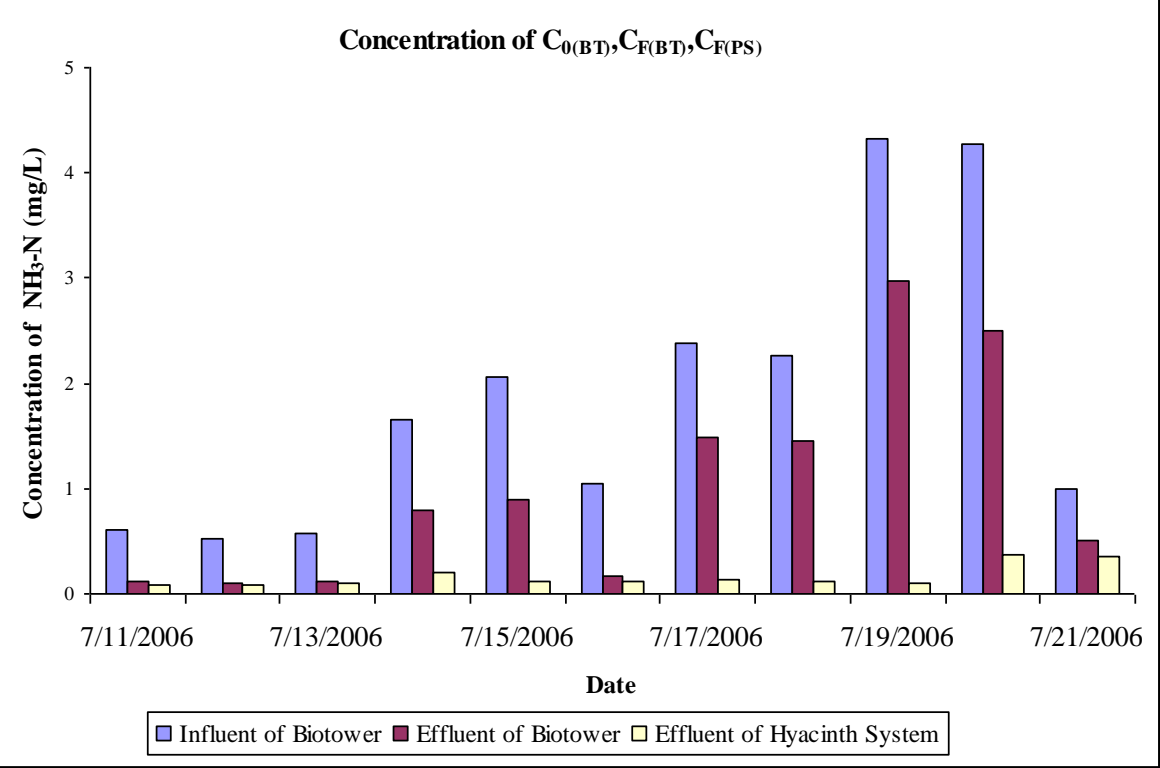

Figure 10. A-N Levels at $\mathrm{C}_{0(\mathrm{BT})}, \mathrm{C}_{\mathrm{F}(\mathrm{BT})}$ and $\mathrm{C}_{\mathrm{F}(\mathrm{PS})}$ versus Detention Time 


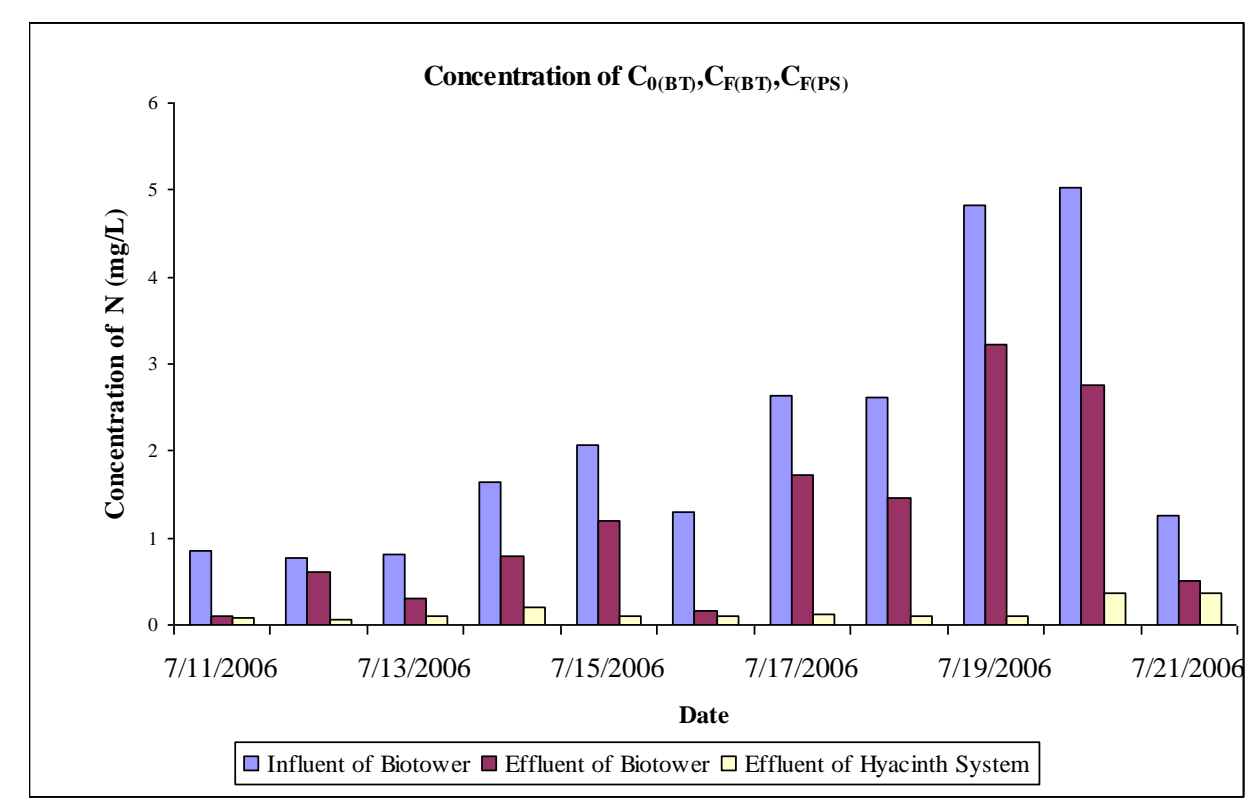

Figure 11. Total $N$ Levels at $C_{0(\mathrm{BT})}, \mathrm{C}_{\mathrm{F}(\mathrm{BT})}$ and $\mathrm{C}_{\mathrm{F}(\mathrm{PS})}$ versus Detention Time

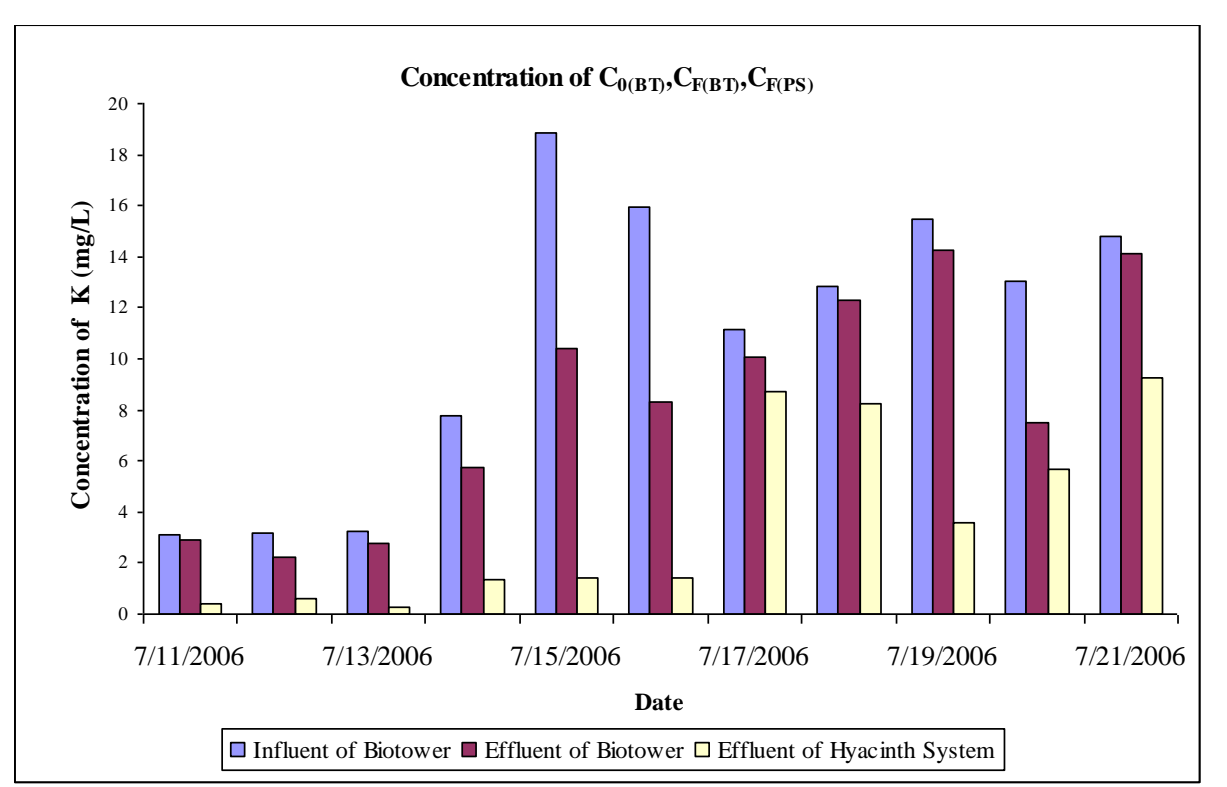

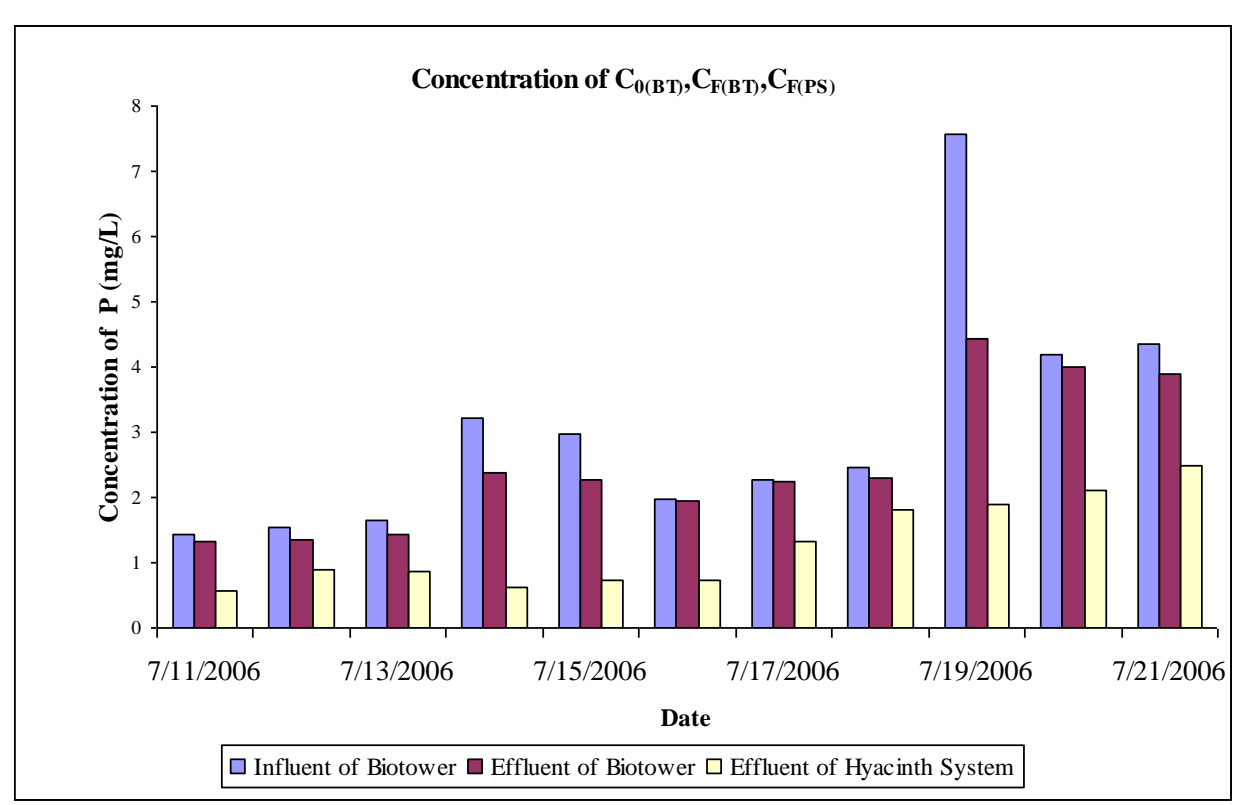

Figure 12. Total $P$ Levels at $C_{0(\mathrm{BT})}, \mathrm{C}_{\mathrm{F}(\mathrm{BT})}$ and $\mathrm{C}_{\mathrm{F}(\mathrm{PS})}$ versus Detention Time

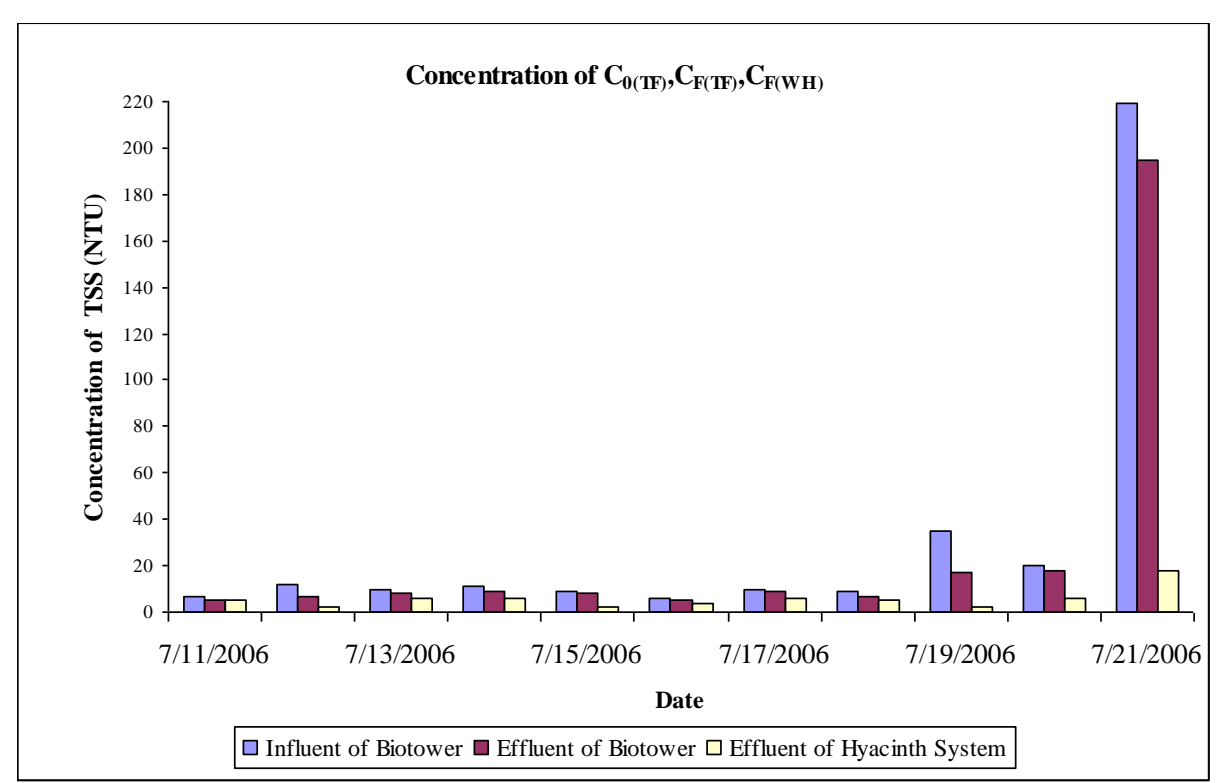


UNIMAS E-Journal of Civil Engineering, Vol. 4: Issue 1 /April 2013

Figure 13. Total $K$ Levels at $C_{0(\mathrm{BT})}, \mathrm{C}_{\mathrm{F}(\mathrm{BT})}$ and $\mathrm{C}_{\mathrm{F}(\mathrm{PS})}$ versus Detention Time

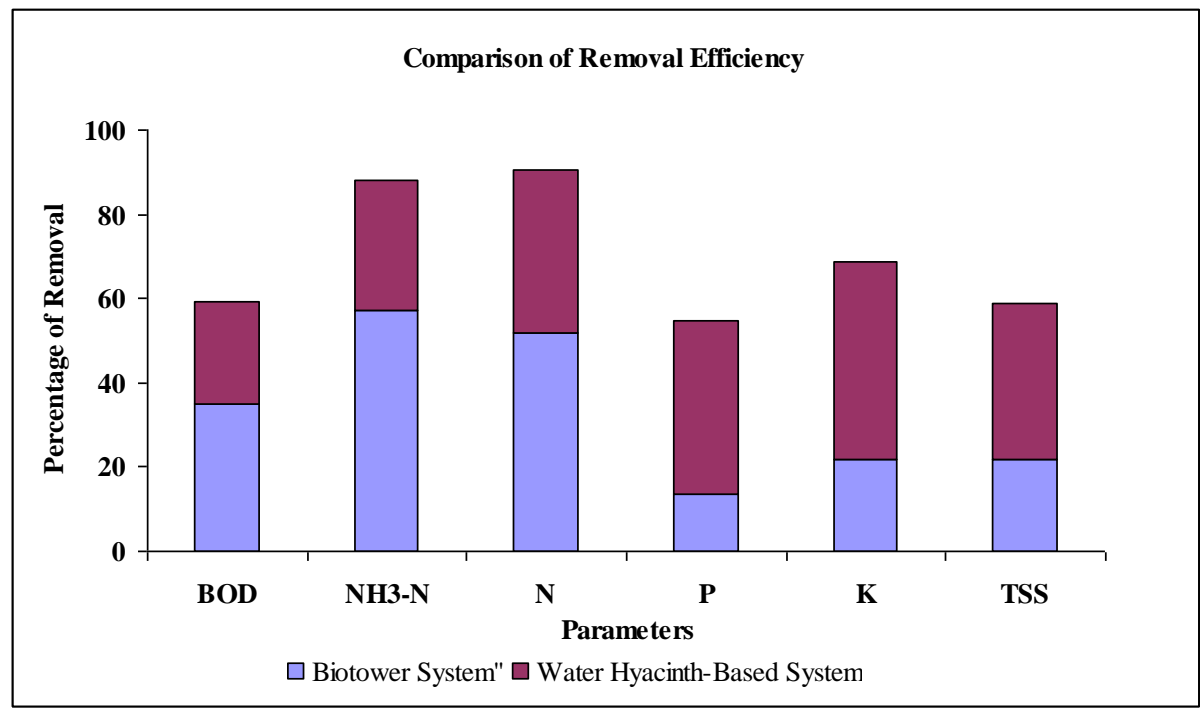

Figure 15. Removal Efficiencies of MFB and FSW Wetland
Figure. 14. TSS Levels at $C_{0(B T)}, C_{F(B T)}$ and $C_{F(B S)}$ versus Detention Time 


\section{CONCLUSIONS}

$\mathrm{P}$

ERFORMANCE evaluation of the 3-stage treatment system for domestic wastewater was carried out to determine the system's efficiencies for removal of O\&G, organic matters and nutrients. For HBF, the CFU flow pattern had achieved an average removal efficiency of 53\% while the PFD pattern achieved an average efficiency of $73.5 \%$. From this study, it can be concluded that the removal efficiencies achieved by MFB were approximately 35.0\% BOD, 57.4\% $\mathrm{NH}_{3}-\mathrm{N}, 51.8 \% \mathrm{~N}, 13.4 \% \mathrm{P}, 21.8 \% \mathrm{~K}$, and $21.9 \%$ reduction in turbidity level, whilst the Pistia Stratiotes-based FSW wetland achieved approximately $24.1 \% \mathrm{BOD}, 30.6 \% \mathrm{NH}_{3}-\mathrm{N}, 38.0 \% \mathrm{~N}, 41.5 \% \mathrm{P}, 46.7 \% \mathrm{~K}$, and $31.7 \%$ reduction in turbidity level. The combined overall system removal efficiencies (i.e., MFB and Pistia Stratiotes-based FSW wetland operating in series) were approximately $59.2 \%$ for $\mathrm{BOD}, 87.9 \%$ for $\mathrm{NH}_{3}-\mathrm{N}, 90.6 \%$ for $\mathrm{N}, 54.9 \%$ for $\mathrm{P}, 68.5 \%$ for $\mathrm{K}$, and $59.0 \%$ reduction on turbidity levels. It can also be concluded that the daily uptake or removal rates (mg/kg-day) of

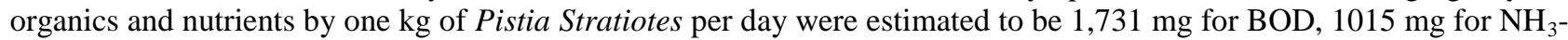
$\mathrm{N}, 1,206 \mathrm{mg}$ for $\mathrm{N}, 1,468 \mathrm{mg}$ for P, and 5,431 mg for K. Based on the performances or removal efficiencies of the 3stage treatment system, the system had proven to be up-scalable, besides possessing immense commercialization potential.

\section{ACKNOWLEDGEMENT}

The authors convey their appreciation to the Graduate Studies and Research Support Division and the financial support of the University of Malaysia Sarawak.

\section{REFERENCES}

[1] S.H. Abdullatif, P.L. Law, H.H. Lau, A. Baharun. (2008). "Optimum coalescence plate arc length for removal of oil droplets from wastewaters." Journal of Engineering Science \& Technology, 2(3), pp. 247-259. Available: http://jestec.taylors.edu.my/Vol\%202\%20Issue\%203\%20December\%2007/247-259\%20Almarouf.pdf

[2] G. J. Alaerts, M. R. Mahbubar, P. Kelderman. (1996). "Performance analysis of a fullscale duckweed covered sewage lagoon." Water Resources Development, 30(4), pp. 843-852. Available: doi:10.1016/0043-1354(95)00234-0

[3] J. Arianne, "Can natural products pick up oil as effectively as polypropylene." Selah Science Project Grade 6 and 7 of 2002, 2006. Available: http://www.Selah.K12.Wa.Us/SOAR/Sciproj2002/Ariannej.Html -->

[4] B. Barraza, P. Sanchez, "What makes the best oil spill cleaner: hair, cotton, or feathers," California State Science Fair 2001 Project Summary, 2001. Available:

http://www.usc.edu/CSSF/History/2001/Projects/J0801.pdf

[5] Brentwood Accupac Cross Flow Media, Brentwood Industries, 2004. Available: http://www.brentwoodprocess.com/crossflow.html

[6] H. Brix, H Schierup. (1989). "The use of aquatic macrophytes in water pollution control," Ambio, 18(2), pp. 100-107. Available: http://mit.biology.au.dk/ biohbn/hansbrix/pdf files/Ambio 1989 100-107.pdf

[7] R.A. Corbitt, Standard Handbook of Environmental Engineering, Mc-Graw Hill Publication, New York, United States of America (USA), 1989.

[8] M. Csuros, Environmental Sampling and Analysis, Lewis Publishers, CRC Press. New York, United States of America (USA), 1997.

[9] A. Gray, "Logarithmic spirals," Modern Differential Geometry of Curves and Surfaces with Mathematica, 2nd Ed. Boca Raton, FL: CRC Press, 1997, pp. 40-42.

[10] A. Gray, "Logarithmic spirals.” Modern Differential Geometry of Curves and Surfaces with Mathematica, 2nd Ed. Boca Raton, FL: CRC Press, 1997, pp. 90-92.

[11] R. Haberl, R. Perfler, H. Mayer. (1995). “Constructed wetlands in Europe,” Water, Science and Technology, 32 (3), pp. 305-315. Available: http://www.iwaponline.com/wst/03203/0305/032030305.pdf

[12] S.A. Haidar, "A Phase separator with inclined parallel arc coalescing plates (ipacp) for removal of physically emulsified and free oils from wastewater." Ph.D. dissertation, Department of Civil Engineering, Faculty of Engineering, Universiti Malaysia Sarawak (UNIMAS), Malaysia, 2008. Available: http://cais-mill.unimas.my/search

[13] M.J. Hammer, M.J.J. Hammer, Water And Wastewater Technology, Pearson Prentice-Hall Inc., Upper Saddle River, New Jersey, United States of America, 2004.

[14] Instruction Manual: Oil Content Analyzer-OCMA-310, HORIBA, Japan, 2005. Available: http://www.horiba.cz/OCMA-310.pdf

[15] S.P. Howard, D.R. Rowe, G. Tchobangolous, "Environmental engineering," Civil Engineering Series, McGraw-Hill International Editions, Singapore, 1985.

[16] W. Kirchhof (1988). "Wastewater treatment in low cost bamboo biotowers and pond system," in Proceedings of the International Bamboo Workshop held in Cochin, India. Available: http://www.inbar.int/publication/txt/INBAR_PR_02.htm

[17] S.S. Krishnan, A. Cancilla, R.E. Jervis. (1988). Wastewater treatment for heavy metal toxins using plant and hair as adsorbents. Pubmed, 68, pp. 267-73. Available: http://www.ncbi.nlm.nih.gov/sites/entrez

[18] P. Kumar, R.J. Garde. (1989). Potentials of Water Lettuce for Sewage Treatment, Research Journal of the Water Pollution Control Federation, $61(11 / 12)$, pp 1702-1706.

[19] P.L. Law, Y.W. Oon, L.H. Ngu. (2005). “A micro-scale wastewater treatment system for domestic effluents,” Journal of Science and Technology in the Tropics, 1(2), pp. 147-155.

[20] P.L. Law, L.H. Ngu, K.K. Wong, A.A. Rahman. (2006). Development and performance tests of a separator for removal of physically emulsified and free oils from wastewaters." Journal of the Institution of Engineers, Malaysia (IEM), 67(2), pp. 10-19. Available: http://www.iem.org.my/wapi/mctweb.dll/getObject?mid=IEMWEB-MAIN2\&ObjID=225

[21] L. Mandi. (1994). Marrakesh wastewater purification experiment using vascular aquatic plants eichhornia crassipes and lemna gibba. Water Science \& Technology, 29(4), pp. 283-287.

[22] R. Mars, "Greywater Treatment with Macrophytes," Greywater Reuse Systems. Midland Business Centre, Washington,2004. Available: 
http://www.greywaterreuse.com.au/index.php/Greywater-Reuse-Systems/Greywater-Treatment-with-Macrophytes.html

[23] E. J. Middlebrooks. (1995). Upgrading pond effluents: an overview. Water, Science \& Technology, 31(12), pp. 353-368. Available: http://www.iwaponline.com/wst/03112/0353/031120353.pdf

[24] National Research Council (NRC), "Using oil pollution dispersants on the sea." National Academy Press, Washington, D.C,1989. Available: http://www.nap.edu/openbook.php?record id=736\&page=R2

[25] L.H. Ngu. "Development and optimization of a circular phase separator with dual angle coalescence plates for removal of suspended solids, free and physically emulsified oils from wastewaters." Ph.D. dissertation, Department of Civil Engineering, Faculty of Engineering, Universiti Malaysia Sarawak (UNIMAS), 2008. Available:http://cais-mill.unimas.my/search

[26] Y.W. Oon, "Development and performance evaluation of a 3-stage treatment system for domestic wastewater." M.Eng Thesis, Department of Civil Engineering, Faculty of Engineering, Universiti Malaysia Sarawak (UNIMAS), Malaysia, 2008. Available: http://caismill.unimas.my/search

[27] Y.W. Oon, "A micro-scale wastewater treatment system for domestic effluents." B.Eng Thesis, Department of Civil Engineering, Faculty of Engineering, Universiti Malaysia Sarawak (UNIMAS), Malaysia, 2005. Available:http://cais-mill.unimas.my/search

[28] G. Oron. (1990). "Economic considerations in wastewater treatment with duckweed for effluent and nitrogen renovation." Research Journal WPCF, 62(5), pp. 692-696. Available: http://www.jstor.org/pss/25043900

[29] T.D. Reynolds, Unit Operations and Processes in Environmental Engineering, Boston, Massachusetts, United States of America (USA), 1982.

[30] J.F. Tamar, "Toil with oil,” California State Science Fair 2004 Project Summary. 2004. Available: http://www.usc.edu/CSSF/History/2004/Projects/J08.pdf

[31] G. Tchobangoglous, F.L. Burton, Wastewater Engineering: Treatment, Disposal, and Reuse, Third Edition. Metcalf \& Eddy, Inc., USA, 1991.

[32] P. Tensie, "Oil absorbency of polypropylene pads vs. natural products." Selah Science Project Grade 6 and 7, 2006. Available:http://www.selah.k12.wa.us/soar/sciproj2006/TensieP.html

[33] Wastewater technology fact sheet trickling filters, EPA 832-F-00-014, United States Environmental Protection Agency (USEPA), Office of Water, Washington, D.C.,2000. Available: http://www.epa.gov/owm/mtb/trickling filter.pdf

[34] Wastewater technology fact sheet trickling filter nitrification, EPA 832-F-00-015, United States Environmental Protection Agency (USEPA), Office of Water, Washington, D.C., 2000. Available: http://www.epa.gov/OWM/mtb/trickling_filt_nitrification.pdf

\section{NOMENCLATURE}

$\mathrm{C}_{\mathrm{o}(\mathrm{OG})} \quad$ Oil\&Grease Filter Influent

$\mathrm{C}_{1(\mathrm{OG})}$ Oil\&Grease Filter Intermediate Effluent

$\mathrm{C}_{\mathrm{o}(\mathrm{BT})} \quad$ Oil\&Grease Filter Effluent / Biotower Influent

$\mathrm{C}_{\mathrm{F}(\mathrm{BT})} \quad$ Biotower Effluent / Hyacinth-Based FSW Influent

$\mathrm{C}_{\mathrm{F}(\mathrm{PS})} \quad$ Pistia Stratiotes-Based FSW Effluent 